\title{
STUDIES ON STRENGTH BEHAVIOR OF HIGH VOLUMES OF SLAG CONCRETE
}

\author{
T. Vijaya Gowri, P. Sravana, P. Srinivasa Rao \\ ${ }^{1}$ Associate Professor, CMRTC, Hyderabad \\ ${ }^{2}$ Professor in Civil Engineering Department, JNTUH University, Hyderabad \\ ${ }^{3}$ Professor in Civil Engg, Department in JNTUH University, Hyderabad
}

\begin{abstract}
The Ground Granulated Blast Furnace Slag (GGBFS) is a waste of industrial material. It is relatively more recent pozzolanic material that has received considerable attention in both research and application. It is now recognized as a desirable cementitious ingredient of concrete. This research study presents the study of behavior of high volumes of slag concrete. The influence of slag content on Compressive strength, Split tensile strength and Flexural strength of High volumes of slag concrete (Cement : GGBFS is 50:50) specimens of different water-binder ratios are investigated for 28 Days, 90 Days, 180 Days and 360 Days. Different waterbinder ratios ranging from 0.55 to 0.27 are considered for investigation. From the results, the relationship is developed between Compressive Strength, Split Tensile strength and Flexural Strength of High Volumes of Slag Concrete.
\end{abstract}

Key words: High Volumes of Slag Concrete, GGBFS, Compressive Strength, Split Tensile strength, Flexural Strength. $* * *$

\section{INTRODUCTION}

Cement, mortar and concrete are the most widely used construction material all over the world. The search for any material, which can be used as an alternative or as a supplementary for cement should lead to global sustainable development and lowest possible environmental impact. In recent years the use of GGBFS concrete is well recognized. Concrete mixes prepared by supplementary mineral admixtures such as Slag, Fly ash, Silica fume as partial replacement of ordinarily Portland cement gives new idea to reduce permeability of concrete.

Combining GGBFS and OPC at mixer is treated as equivalent to factory made PSC. Concrete with different properties can make by varying the proportions of GGBFS. The strength values corresponding to ' 0 ' day curing period mean the strength of the specimens after 30 days Plain Water curing. It is clearly demonstrated that the concrete specimens with cement slag proportions 70:30 gives lower strength deterioration for longer curing periods. In case of plain water curing, OPC concrete shows higher strength at initial ages than that for slag concrete. But for relatively longer curing periods, the differences between the results are seen to be decreased [1].

Curing concrete is one of the most important steps in concrete construction and regrettably, one of the most neglected. Effective curing is absolutely essential for surface durability. The curing of concrete involves maintaining a proper moisture vapor transmission rate $(2 \%$ mvtr) immediately after concrete placement and throughout the ensuing period of approximately 28 days. In recent years there has been considerable discussion regarding the effects of curing on concrete containing Portland blast-furnace slag cement and concrete containing GGBF slag as a separate constituent [2].

As reported by Roy and Idorn, the early age strength developments of slag-cement mortars are lower than for OPC. However, by three days, the strengths of slag-cement mortars are equal to or greater than the OPC [3].

Wimpenny, determined that in general the highest 91-day compressive strength of slag mixes is obtained under $20^{\circ} \mathrm{C}$ curing, the strength decreasing as the curing temperature is lowered. Increasing the curing temperature to $40^{\circ} \mathrm{C}$ leads to a drop in strength at longer ages, in the case of OPC control mixes below those recorded at $5^{\circ} \mathrm{C}$ [4].

A1-Kaisi, also showed that OPC and slag concretes cured under isothermal conditions at temperature of $20^{\circ} \mathrm{C}$ tend to show a higher strength beyond 28 days than concretes cured isothermally at temperatures between $40-60^{\circ} \mathrm{C}$ [5]. Pratas found from experiment that the strength loss in high volume slag concrete is more than normal concrete when the curing was not properly done. Curing duration of high volume slag cement concrete must be more than plain concrete [6].

Sasan Parniani stated that Concrete contain GGBF slag is more impressionable to poor curing conditions than concrete without GGBF slag. It means that strength loss in high volume slag concrete is more than normal concrete when the curing 
was not properly done. Curing duration of high volume slag cement concrete must be more than plain concrete [7].

David N. Richardson concluded that the compressive strengths of the 70\% GGBFS PC field mix at all ages up to one year were about 2000 psi lower than the plain PC mix. The addition of a high range water reducer (HRWR) to the slag-PC mix narrowed the difference to about $1300 \mathrm{psi}$. When using the same PC type for both the control and slag-PC laboratory mixes, all slag-PC mixes had greater strengths than the plain PC mix [8].

Atul Dubey, showed that Concrete property can be maintained with advanced mineral admixtures such as blast furnace slag powder as partial replacement of cement 5 to $30 \%$. Compressive strength of blast furnace slag concrete with different dosage of slag was studied as a partial replacement of cement. The optimum replacement of Ground Granulated Blast Furnace Slag Powder to cement without changing much the compressive strength is $15 \%$ [9].

According to Mohd Warid Hussin, the optimum compressive strength obtained for $50 \%$ slag replacement cement grout was above $30 \mathrm{MPa}$ and its flexural strength was above $9 \mathrm{MPa}$ under water curing condition. Result of drying shrinkage test strengthened the finding that the replacement of 50\% slag as binder to cement mix with proper mix proportion is suitable to be used in normal grade concrete repairs under tropical climate [10].

As per Irene K. LaBarca, grade 120 slag cement is a viable material for use in highway pavement concrete design. While variations in mix materials and curing conditions cause changes in the performance of the hardened concrete, many options exist for combinations of materials that are successful with grade 120 slag cement at replacement levels up to $50 \%$ [11]. Mohammed Nadeem, Concrete of M20, M30 and M40 grades were considered for a W/C ratio of $0.55,0.45$ and 0.40 respectively for the replacements of $0,30,50,70$ and $100 \%$ of aggregates (Coarse and Fine) by slag. Whole study was done in two phases, i.e. replacement of normal crushed coarse aggregate with crystallized slag and replacement of natural fine aggregate with granular slag. The investigation revealed improvement in compressive strength, split tensile and flexure strength over control mixes by 4 to $8 \%$. The replacement of $100 \%$ slag aggregate (coarse) increased concrete density by about 5 to $7 \%$ compared to control mix. The slag could be effectively utilized as coarse and fine aggregates in all the concrete applications [12].

P. Venkata Mallikarjun Rao that concluded the substitution of natural coarse aggregate with slag increases compressive strength, flexural and Tensile Strength [13].

VENU MALAGAVELLI explained that $\mathrm{M}_{30}$ concrete with partial replacement of cement with Ground Granulated
Blastfurnace Slag (GGBS) and sand with the ROBO sand (crusher dust). The cubes and cylinders are tested for both compressive and tensile strengths. The partial replacement of cement with GGBS and sand with ROBO sand helped in improving the strength of the concrete substantially compared to normal mix concrete [14].

Yousef Zandi1, explained that for 28 days, the flexural strength of the Together grinding Portland slag cements show more or less the same values with the separately ground ones for all of the Blaine fineness values. Finally, the flexural strength of the separately ground Portland slag cements show higher values than the Together grinding ones again for all of the Blaine fineness values at 90 days [15].

Gopal Charan Behera, concluded from experiment that the workability increases with increase in the percentage of slag as coarse aggregate in place of normal coarse aggregate. The weight of the cube increases with increase in the percentage of slag as coarse aggregate. The increase is nominal, so the concrete with slag can be used in structural works. Compressive strength increases with increase in the percentage of slag, so it is better to design compression members with it. Split tensile strength increases with increase in the percentage of slag, which can be regarded as a good sign from the durability point of view. Flexural strength of concrete with use of slag increases with increase in percentage of slag. There is no such change in the mechanical properties of hardened concrete up to $20 \%$ replacement of natural aggregate with slag [16].

\section{RESEARCH SIGNIFICANCE}

The use of Ground granulated blast furnace slag resulted from the strict enforcement of air-pollution measures designed to stop release of the material into the atmosphere. In the present study an attempt has been made to assess the suitability of Ground granulated blast furnace slag as cement replacement material in concrete making. In this study, the Compressive Strength, Split Tensile Strength and Flexural Strength of High Volumes of Slag Concrete using 50\% GGBFS as replacement material of cement for various water-binder ratios $0.55,0.50$, $0.45,0.40,0.36,0.32,0.30,0.27$ at 28 Days, 90 Days, 180 Days and 360 Days Strengths were found out. And also comparing the Compressive Strength with Split Tensile Strength and Flexural Strength between the different water binder ratios and also with age and relationships were developed between them.

\section{EXPERIMENTAL INVESTIGATION}

CEMENT: Locally available 53 grade of Ordinary Portland Cement (Ultratech Brand.) confirming to IS: 12269 was used in the investigations. The cement is tested for various properties like Normal consistency, specific gravity, Fineness, Soundness, Compressive Strength, and Specific Surface area 
were found to be $28 \%, 3.10,4 \%, 0.5 \mathrm{~mm}, 53 \mathrm{Mpa}$ and 3100 $\mathrm{cm}^{2} / \mathrm{g}$ in accordance with IS:12269-1987.

GGBFS: GGBFS which is available in local market, brought from Steel Plant, Visakhapatnam (Dt.), Andhra Pradesh. The physical requirements in accordance with IS 1727- 1967 (Reaffirmed2008) and chemical requirements in accordance with IS: 12089 - 1987 (Reaffirmed 2008). The GGBFS is tested for various properties like Specific gravity and Fineness were found to be 2.2 and $3500 \mathrm{~cm}^{2} / \mathrm{g}$.

SUPER PLASTICIZER: The Super plasticizer utilized was supplied by internationally reputed admixture manufactures. Endure flowcon04 was manufactured by Johnson. Endure flowcon04 is dark brown colored liquid and it is based as sulphonated naphthalene formaldehyde (SNF) super plasticizer. It complies with IS:9103-1999, BS5075, ASTM C494 was used. The super plasticizer is tested for properties like density and $\mathrm{pH}$ were found to be 1.2 and minimum 6 .

FINE AGGREGATE: The locally available river sand is used as fine aggregate in the present investigation. The sand is free from clay, silt, and organic impurities. The sand is tested for various properties like specific gravity, water absorption and fineness modulus of fine aggregate were found to be 2.55,1.72 and 2.74 in accordance with IS:2386-1963.

COARSE AGGREGATE: Machine crushed angular granite metal of $20 \mathrm{~mm}$ nominal size from the local source is used as coarse aggregate. It is free from impurities such as dust, clay particles and organic matter etc., The coarse aggregate is also tested for its various properties. The specific gravity, water absorption and bulk density and fineness modulus of coarse aggregate were found to be $2.65,0.38,1490 \mathrm{~kg} / \mathrm{m}^{3}$ and 7.16 respectively.

WATER: Locally available water used for mixing and curing which is potable, shall be clean and free from injurious amounts of oils, acids, alkalis, salts, sugar, organic materials or other substances that may be deleterious to concrete or steel.

\section{MIX DESIGN}

Table.1 Quantities of Material required per One $\mathrm{Cu}$. m. of High Volumes of Slag Concrete

\begin{tabular}{|c|c|c|c|c|c|c|c|}
\hline $\begin{array}{c}\text { W/Binder } \\
\text { ratio }\end{array}$ & $\begin{array}{c}\text { Water } \\
(\mathbf{L t s})\end{array}$ & $\begin{array}{c}\text { Cement } \\
(\mathbf{k g})\end{array}$ & $\begin{array}{c}\text { GGBS } \\
(\mathbf{k g})\end{array}$ & $\begin{array}{c}\text { Fine } \\
\text { Aggregate } \\
(\mathbf{k g})\end{array}$ & $\begin{array}{c}\text { Coarse } \\
\text { Aggregate } \\
(\mathbf{k g})\end{array}$ & $\begin{array}{c}\text { Super } \\
\text { Plasticizer(ml) }\end{array}$ & $\begin{array}{c}\text { Slump } \\
\text { Values } \\
(\mathbf{m m})\end{array}$ \\
\hline 0.55 & 176 & 160 & 160 & 763 & 990 & 0 & 75 \\
\hline 0.50 & 176 & 176 & 176 & 749 & 971 & 0 & 80 \\
\hline 0.45 & 176 & 196 & 196 & 715 & 966 & 9 & 65 \\
\hline 0.40 & 176 & 220 & 220 & 662 & 971 & 45 & 90 \\
\hline 0.36 & 176 & 244 & 244 & 625 & 961 & 55 & 100 \\
\hline 0.32 & 176 & 275 & 275 & 587 & 936 & 100 & 120 \\
\hline 0.30 & 176 & 293 & 293 & 529 & 959 & 100 & 130 \\
\hline 0.27 & 176 & 326 & 326 & 477 & 945 & 120 & 140 \\
\hline
\end{tabular}

Table.2 Compressive Strength Split Tensile Strength and Flexural Strength of High Volumes of Slag Concrete at 28 Days.

\begin{tabular}{|c|c|c|c|c|}
\hline \multirow{2}{*}{$\begin{array}{c}\text { Specimen } \\
\text { Notation }\end{array}$} & $\begin{array}{c}\text { W/binder } \\
\text { ratio }\end{array}$ & $\begin{array}{c}\text { Compressive } \\
\text { Strength (Mpa) }\end{array}$ & $\begin{array}{c}\text { 28 Days } \\
\text { Split Tensile } \\
\text { Strength(Mpa) }\end{array}$ & $\begin{array}{c}\text { Flexural } \\
\text { Strength(Mpa) }\end{array}$ \\
\cline { 3 - 5 } & 0.55 & 29.09 & 2.06 & 3.80 \\
\hline HS1 & 0.50 & 30.60 & 2.15 & 3.83 \\
\hline HS2 & 0.45 & 33.90 & 2.61 & 4.10 \\
\hline HS3 & 0.40 & 37.30 & 2.62 & 4.20 \\
\hline HS4 & 0.36 & 42.00 & 2.75 & 4.28 \\
\hline HS5 & 0.32 & 45.00 & 2.91 & 4.32 \\
\hline HS6 & 0.30 & 48.00 & 3.53 & 4.42 \\
\hline HS7 & 0.27 & 54.00 & 3.66 & 4.76 \\
\hline HS8 & & & & \\
\hline
\end{tabular}


Table.3 Compressive Strengths of High Volumes of Slag Concrete at 28 Days, 90 Days, 180Days and 360 Days.

\begin{tabular}{|c|c|c|c|c|c|}
\hline \multirow{2}{*}{$\begin{array}{c}\text { Specimen } \\
\text { Notation }\end{array}$} & \multirow{2}{*}{$\begin{array}{c}\text { W/binder } \\
\text { ratio }\end{array}$} & \multicolumn{4}{|c|}{ Compressive Strength (MPa) } \\
\cline { 3 - 6 } & & 28 Days & 90 Days & 180 Days & 360 Days \\
\hline HS1 & 0.55 & 29.09 & 35.70 & 39.26 & 40.55 \\
\hline HS2 & 0.50 & 30.60 & 37.50 & 40.52 & 41.62 \\
\hline HS3 & 0.45 & 33.90 & 40.31 & 43.51 & 45.04 \\
\hline HS4 & 0.40 & 37.30 & 44.00 & 45.51 & 46.57 \\
\hline HS5 & 0.36 & 42.00 & 51.30 & 53.40 & 54.02 \\
\hline HS6 & 0.32 & 45.00 & 53.50 & 54.50 & 56.04 \\
\hline HS7 & 0.30 & 48.00 & 56.50 & 58.50 & 60.09 \\
\hline HS8 & 0.27 & 54.00 & 62.00 & 65.10 & 67.28 \\
\hline
\end{tabular}

Table.4 Compressive Strengths of High Volumes of Slag Concrete at 28 Days, 90 Days, 180Days and 360 Days and their \% increase in strength with respect to 28 Days.

\begin{tabular}{|c|c|c|c|c|c|c|c|c|}
\hline $\begin{array}{c}\text { Specimen } \\
\text { notation }\end{array}$ & $\begin{array}{c}\text { w/b } \\
\text { ratio }\end{array}$ & 28days & 90days & $\begin{array}{c}\text { \% } \\
\text { increase } \\
\mathbf{9 0} \text { days }\end{array}$ & 180days & $\begin{array}{c}\text { \% increase } \\
\text { in 180 days }\end{array}$ & $\begin{array}{c}\text { 360 } \\
\text { Days }\end{array}$ & $\begin{array}{c}\text { \% } \\
\text { increase } \\
\text { in 360 } \\
\text { days }\end{array}$ \\
\hline HS1 & 0.55 & 29.09 & 35.70 & 23 & 39.26 & 35 & 40.55 & 39 \\
\hline HS2 & 0.50 & 30.60 & 37.50 & 23 & 40.52 & 32 & 41.62 & 36 \\
\hline HS3 & 0.45 & 33.90 & 40.31 & 19 & 43.51 & 28 & 45.04 & 33 \\
\hline HS4 & 0.40 & 37.30 & 44.00 & 18 & 45.51 & 22 & 46.57 & 25 \\
\hline HS5 & 0.36 & 42.00 & 51.30 & 22 & 53.40 & 27 & 54.02 & 29 \\
\hline HS6 & 0.32 & 45.00 & 53.50 & 19 & 54.50 & 21 & 56.04 & 25 \\
\hline HS7 & 0.30 & 48.00 & 56.50 & 18 & 58.50 & 22 & 60.09 & 25 \\
\hline HS8 & 0.27 & 54.00 & 62.00 & 15 & 65.10 & 21 & 67.28 & 25 \\
\hline
\end{tabular}

Table.5 Split Tensile Strengths of High Volumes of Slag Concrete at 28 Days, 90 Days, 180Days and 360 Days and their \% increase in strength with respect to 28 Days.

\begin{tabular}{|c|c|c|c|c|c|c|c|c|}
\hline \multirow{2}{*}{$\begin{array}{c}\text { Specimen } \\
\text { notation }\end{array}$} & \multirow{2}{*}{ W/b ratio } & \multicolumn{7}{|c|}{ Split Tensile Strength (Mpa) $\left(\mathbf{f}_{\mathbf{t}}\right)$} \\
\cline { 3 - 9 } & & $\begin{array}{c}\mathbf{2 8} \\
\text { Days }\end{array}$ & $\mathbf{9 0}$ Days & $\begin{array}{c}\mathbf{\%} \\
\text { increase }\end{array}$ & $\mathbf{1 8 0}$ Days & $\begin{array}{c}\mathbf{\%} \\
\text { increase }\end{array}$ & $\mathbf{3 6 0}$ Days & $\begin{array}{c}\mathbf{\%} \\
\text { increase }\end{array}$ \\
\hline HS1 & 0.55 & 2.06 & 2.58 & 25 & 2.71 & 32 & 2.86 & 39 \\
\hline HS2 & 0.50 & 2.15 & 2.66 & 24 & 2.90 & 35 & 3.00 & 40 \\
\hline HS3 & 0.45 & 2.61 & 3.05 & 17 & 3.20 & 22 & 3.48 & 33 \\
\hline HS4 & 0.40 & 2.62 & 3.08 & 18 & 3.23 & 23 & 3.63 & 38 \\
\hline HS5 & 0.36 & 2.75 & 3.22 & 17 & 3.54 & 29 & 3.80 & 38 \\
\hline HS6 & 0.32 & 2.91 & 3.64 & 25 & 3.76 & 29 & 3.95 & 36 \\
\hline HS7 & 0.30 & 3.53 & 4.05 & 15 & 4.23 & 20 & 4.53 & 28 \\
\hline HS8 & 0.27 & 3.66 & 4.19 & 15 & 4.38 & 20 & 4.58 & 25 \\
\hline
\end{tabular}


Table.6 Flexural Strengths of High Volumes of Slag Concrete at 28 Days, 90 Days, 180Days and 360 Days and their \% increase in strength with respect to 28 Days.

\begin{tabular}{|c|c|c|c|c|c|c|c|c|}
\hline \multirow{2}{*}{$\begin{array}{c}\text { Specimen } \\
\text { notation }\end{array}$} & \multirow{2}{*}{ W/b ratio } & \multicolumn{7}{|c|}{ Flexural Strength (Mpa) $\left(\mathbf{f}_{\mathbf{f}}\right)$} \\
\cline { 3 - 9 } & & $\begin{array}{c}\mathbf{2 8} \\
\text { Days }\end{array}$ & $\mathbf{9 0}$ Days & $\begin{array}{c}\text { \% } \\
\text { increase }\end{array}$ & $\mathbf{1 8 0}$ Days & $\begin{array}{c}\text { \% } \\
\text { increase }\end{array}$ & 360 Days & $\begin{array}{c}\text { \% } \\
\text { increase }\end{array}$ \\
\hline HS1 & 0.55 & 3.80 & 4.12 & 8 & 4.22 & 11 & 4.32 & 14 \\
\hline HS2 & 0.50 & 3.83 & 4.20 & 10 & 4.24 & 11 & 4.40 & 15 \\
\hline HS3 & 0.45 & 4.10 & 4.34 & 6 & 4.60 & 12 & 4.70 & 15 \\
\hline HS4 & 0.40 & 4.20 & 4.45 & 6 & 4.84 & 15 & 4.92 & 17 \\
\hline HS5 & 0.36 & 4.28 & 4.60 & 7 & 4.95 & 16 & 5.08 & 19 \\
\hline HS6 & 0.32 & 4.32 & 4.90 & 13 & 5.15 & 19 & 5.20 & 20 \\
\hline HS7 & 0.30 & 4.42 & 5.10 & 15 & 5.22 & 18 & 5.25 & 19 \\
\hline HS8 & 0.27 & 4.76 & 5.25 & 10 & 5.45 & 14 & 5.50 & 16 \\
\hline
\end{tabular}

Table.7 Ratio between Split Tensile and Compressive Strengths (\%) and Flexural and Compressive Strengths (\%) for HVSC at 28Days

\begin{tabular}{|c|c|c|c|c|c|c|}
\hline \multirow[b]{2}{*}{$\begin{array}{l}\text { Specimen } \\
\text { Notation }\end{array}$} & \multirow[b]{2}{*}{$\begin{array}{l}\text { W/binder } \\
\text { ratio }\end{array}$} & \multicolumn{5}{|c|}{28 Days } \\
\hline & & $\begin{array}{l}\text { Compressive } \\
\text { Strength }\end{array}$ & $\begin{array}{c}\text { Split } \\
\text { Tensile } \\
\text { Strength } \\
\text { (Mpa) }\end{array}$ & $\begin{array}{c}\text { Ratio between } \\
\text { Split Tensile and } \\
\text { Compressive } \\
\text { Strengths }(\%)\end{array}$ & $\begin{array}{c}\text { Flexural } \\
\text { Strength } \\
\text { (Mpa) }\end{array}$ & $\begin{array}{c}\text { Ratio between } \\
\text { Flexural and } \\
\text { Compressive } \\
\text { Strengths }(\%)\end{array}$ \\
\hline HS1 & 0.55 & 29.09 & 2.06 & 7.08 & 3.80 & 13.06 \\
\hline HS2 & 0.50 & 30.60 & 2.15 & 7.03 & 3.83 & 12.52 \\
\hline HS3 & 0.45 & 33.90 & 2.61 & 7.70 & 4.10 & 12.09 \\
\hline HS4 & 0.40 & 37.30 & 2.62 & 7.02 & 4.20 & 11.26 \\
\hline HS5 & 0.36 & 42.00 & 2.75 & 6.55 & 4.28 & 10.19 \\
\hline HS6 & 0.32 & 45.00 & 2.91 & 6.47 & 4.32 & 9.60 \\
\hline HS7 & 0.30 & 48.00 & 3.53 & 7.35 & 4.42 & 9.21 \\
\hline HS8 & 0.27 & 54.00 & 3.66 & 6.78 & 4.76 & 8.81 \\
\hline
\end{tabular}




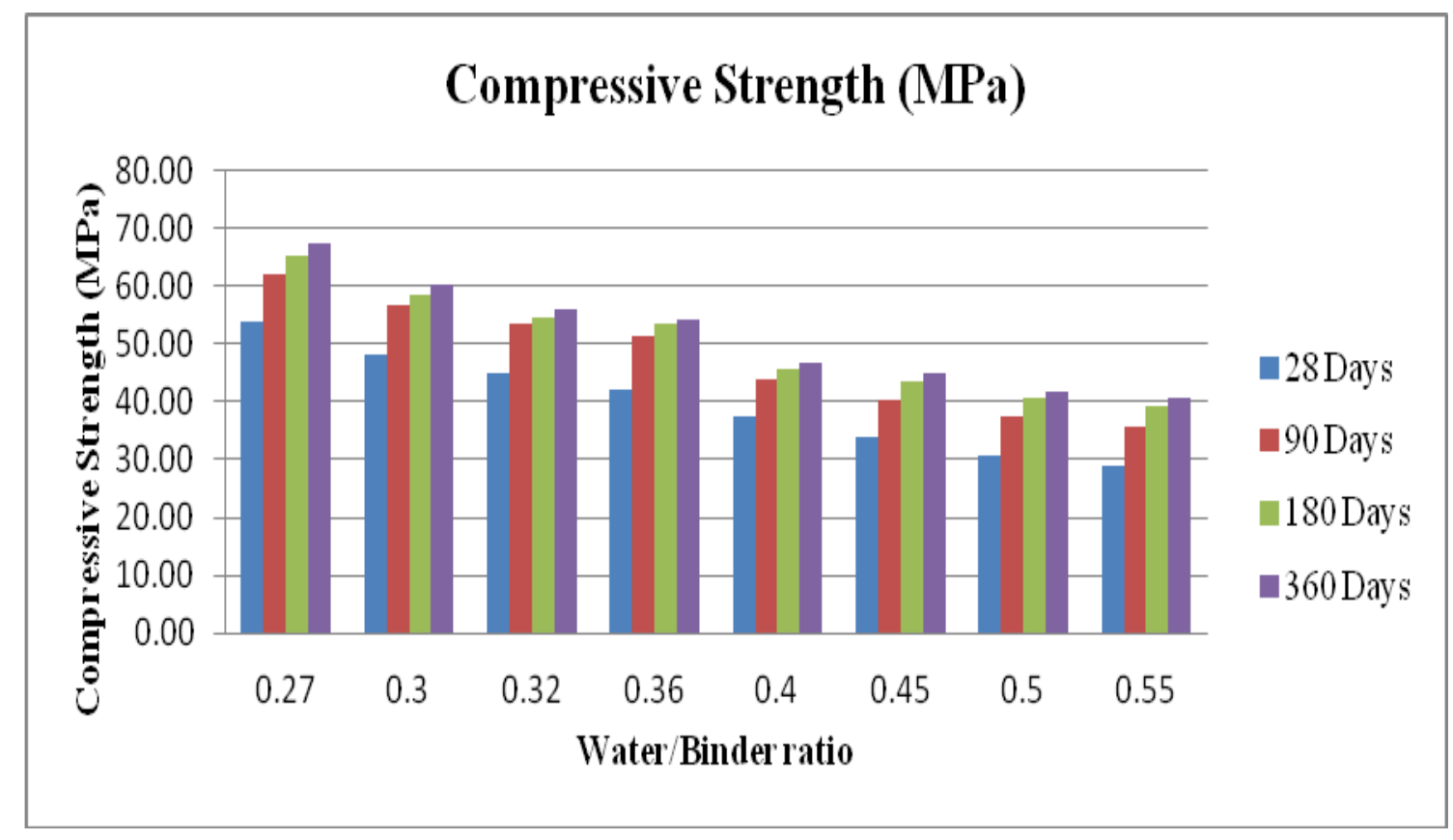

Fig 1 Compressive Strength of HVSC For various W/B ratios at 28 Days, 90 Days, 180 Days and 360 Days.

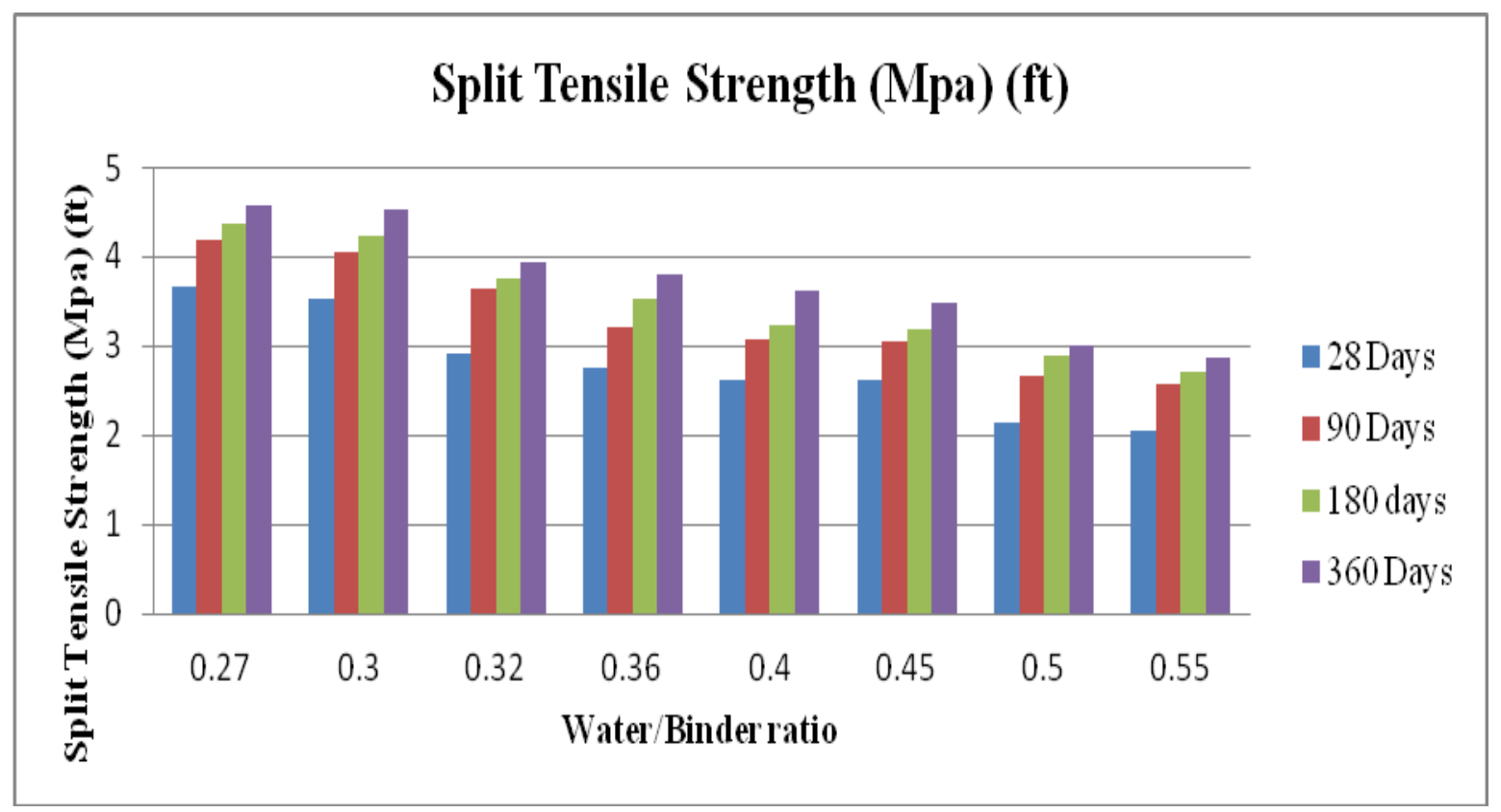

Fig 2 Split Tensile Strength of HVSC For various W/B ratios at 28 Days, 90 Days, 180 Days and 360 Days. 


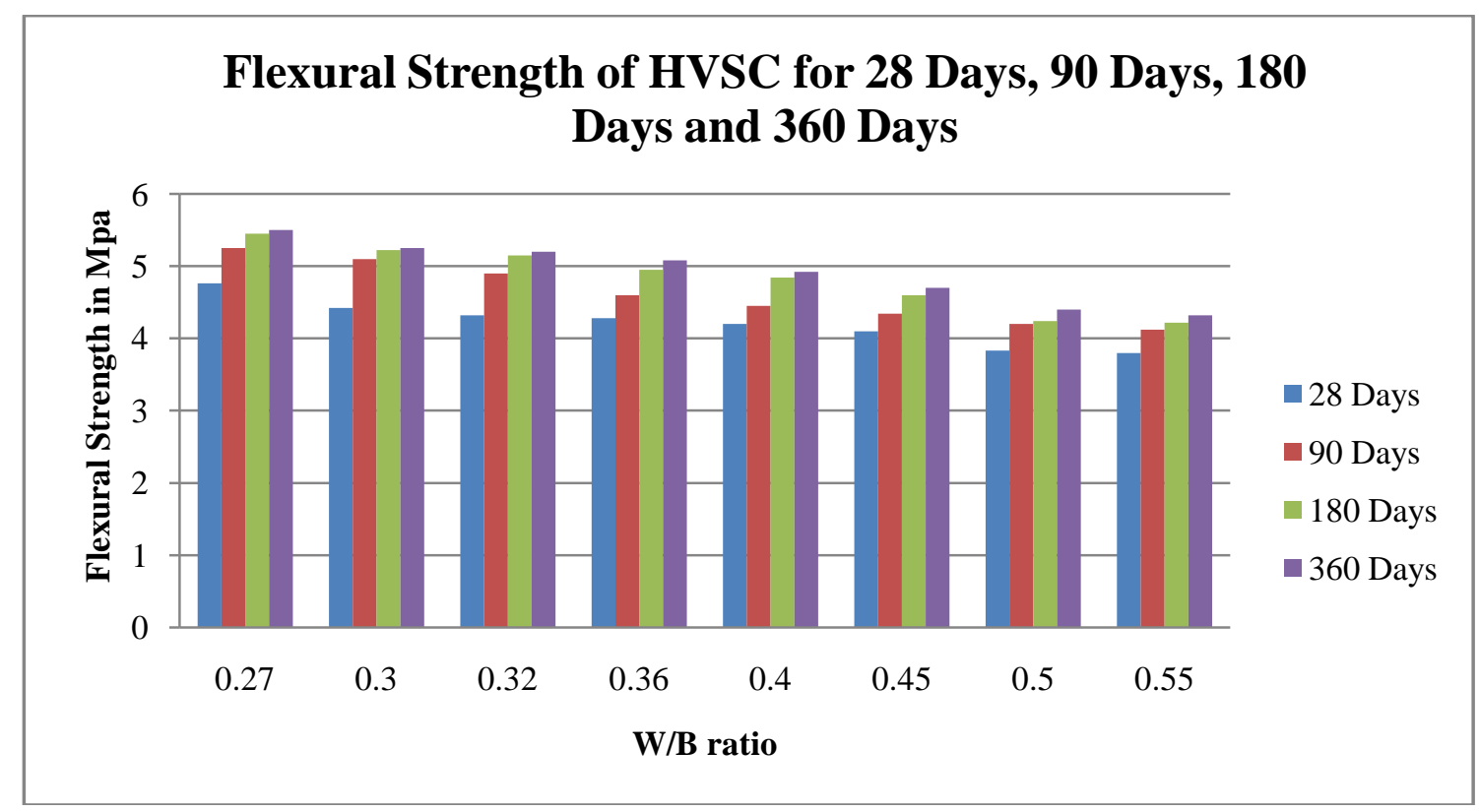

Fig 3 Flexural Strength of HVSC For various W/B ratios at 28 Days, 90 Days, 180 Days and 360 Days.

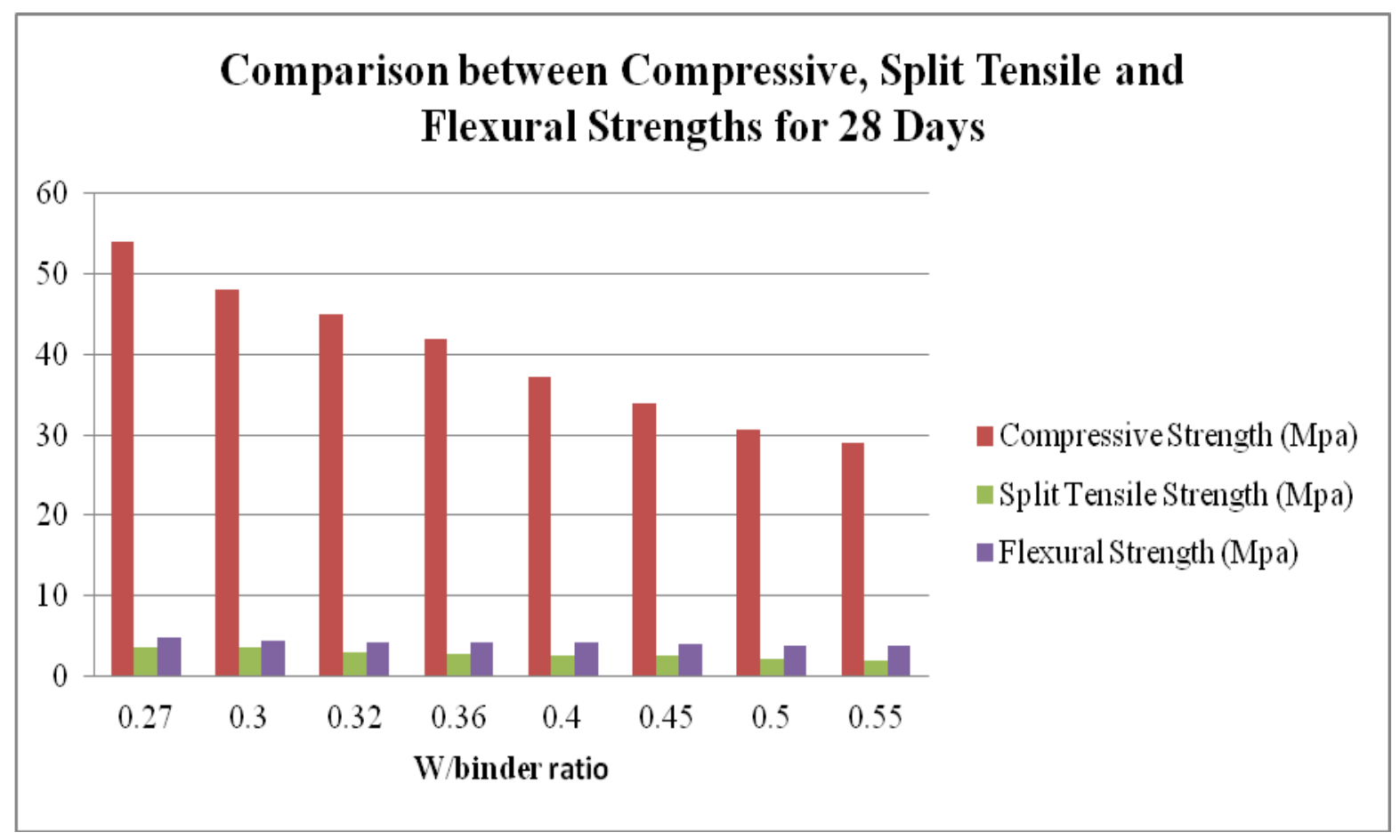

Fig 4 Comparison between Compressive Strength, Split Tensile Strength and Flexural Strength of HVSC For various W/B ratios at 28 Days 


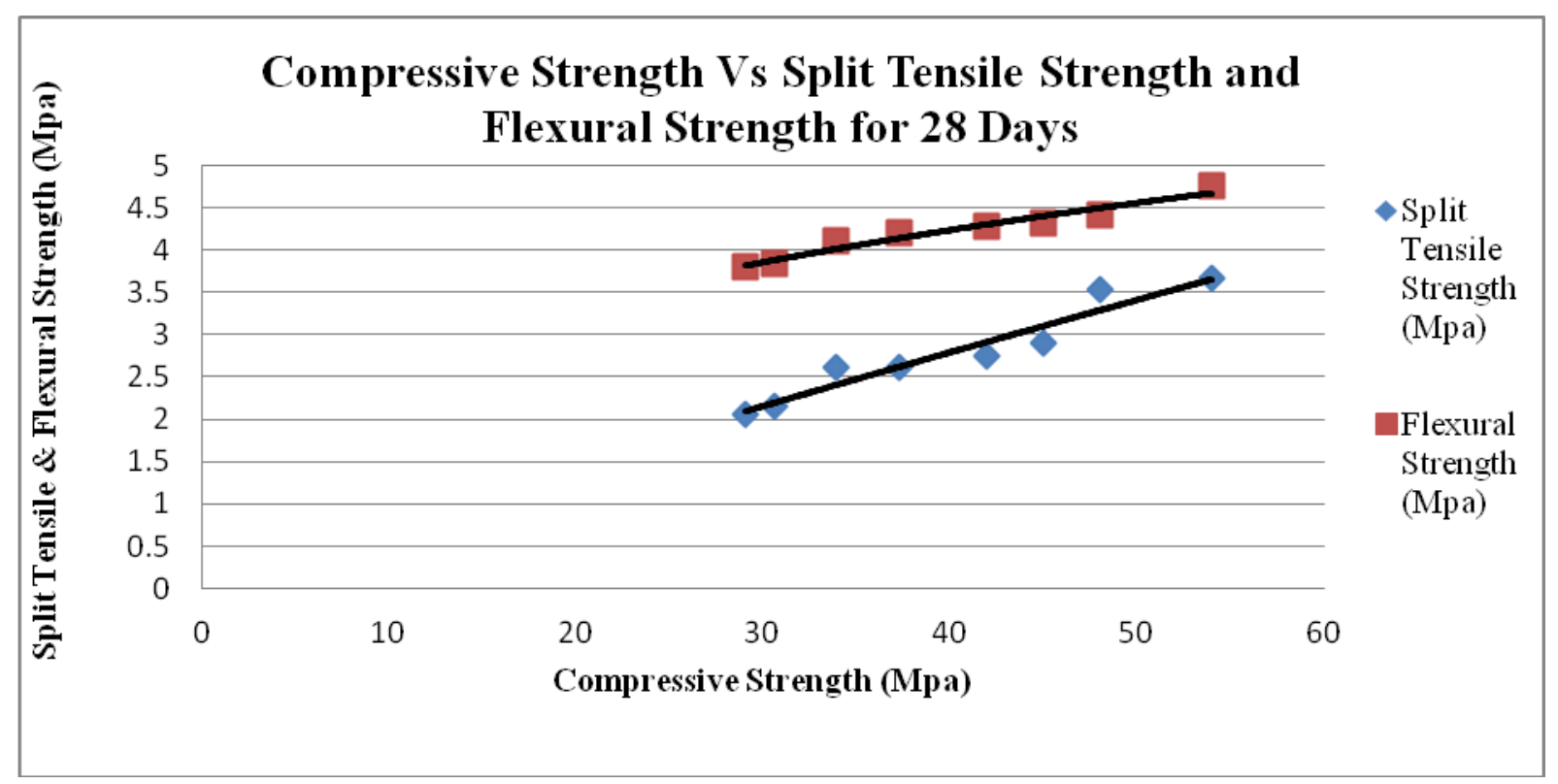

Fig 5 Comparison between Compressive, Split Tensile and Flexural Strengths for 28 Days

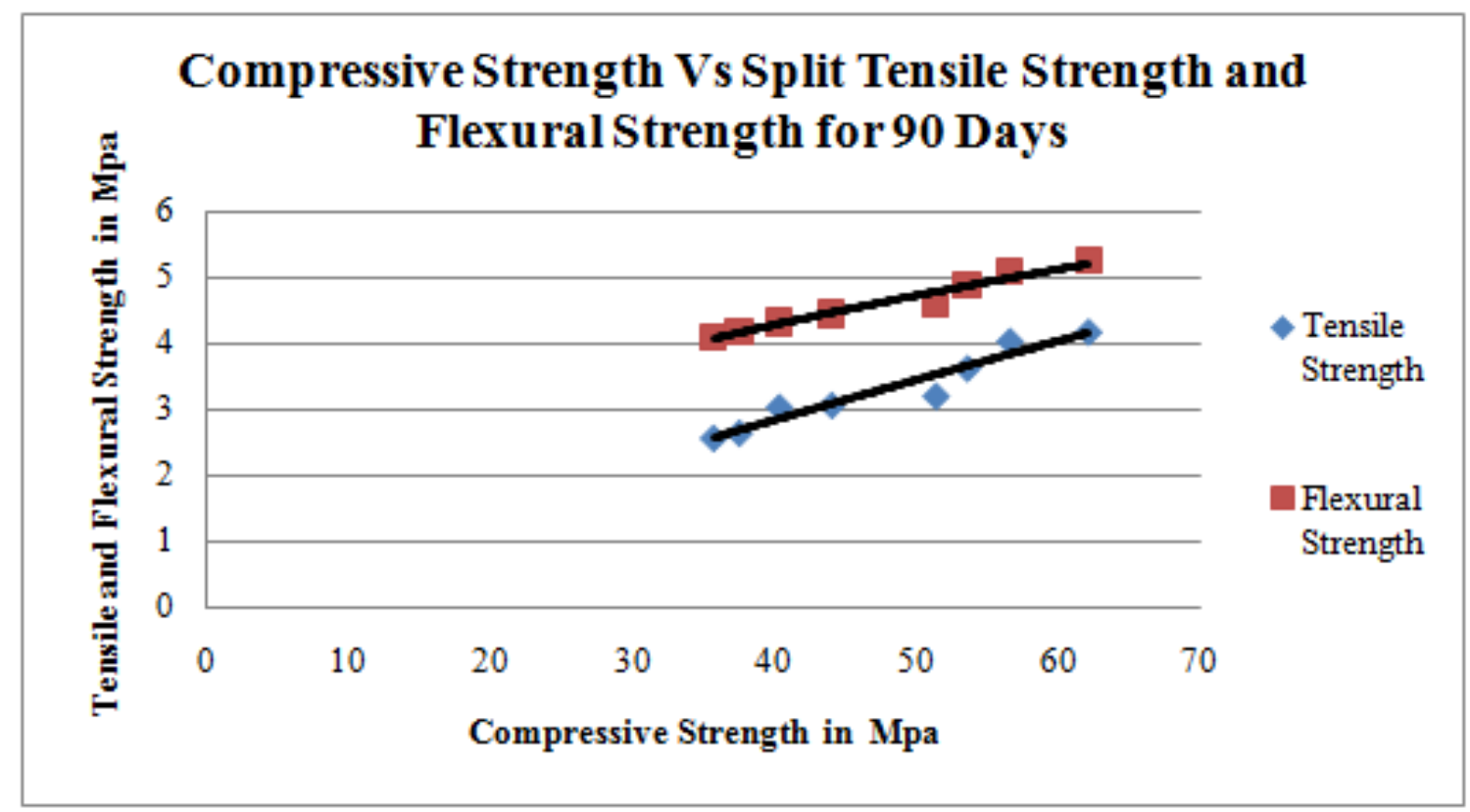

Fig 6 Comparison between Compressive, Split Tensile and Flexural Strengths for 90 Days 


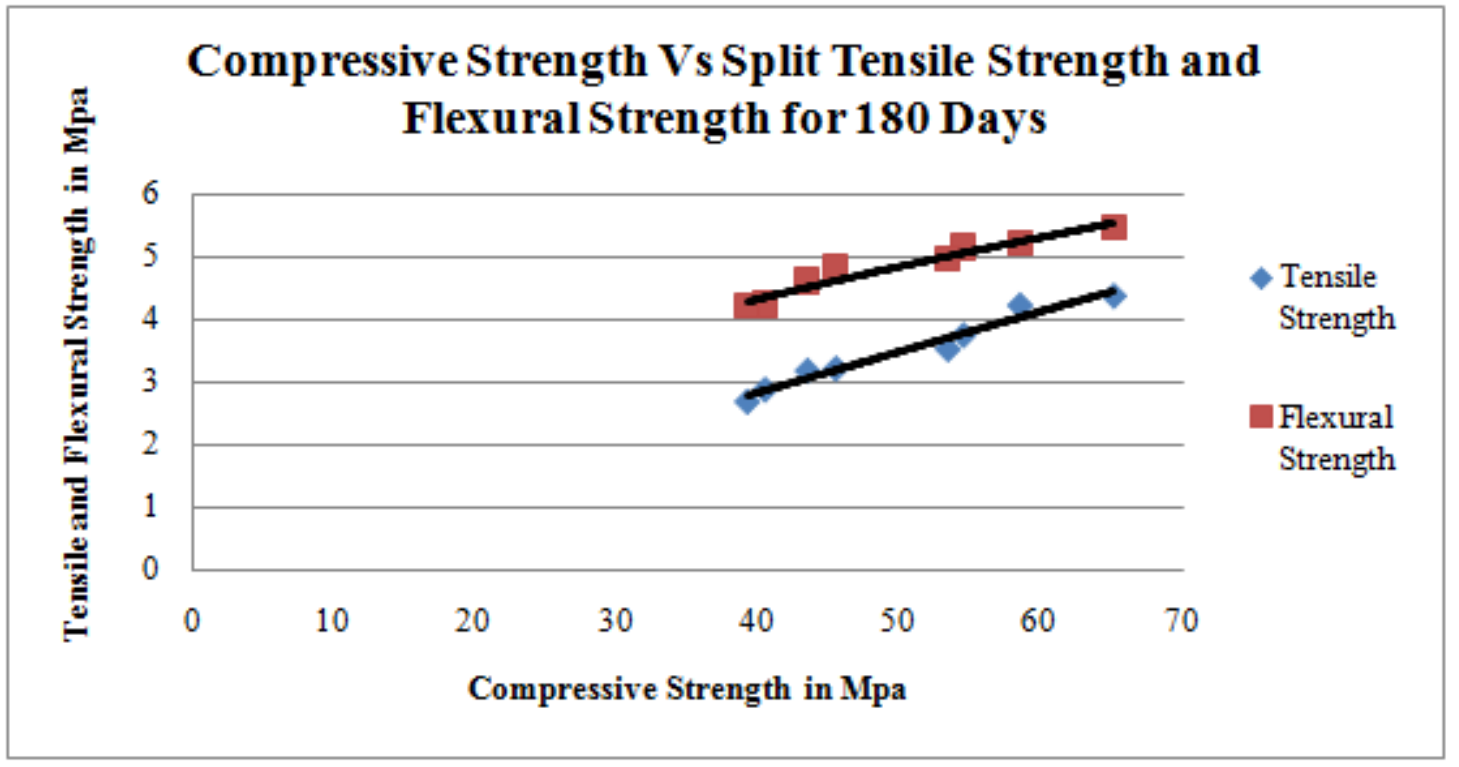

Fig 7 Comparison between Compressive, Split Tensile and Flexural Strengths for 180 Days

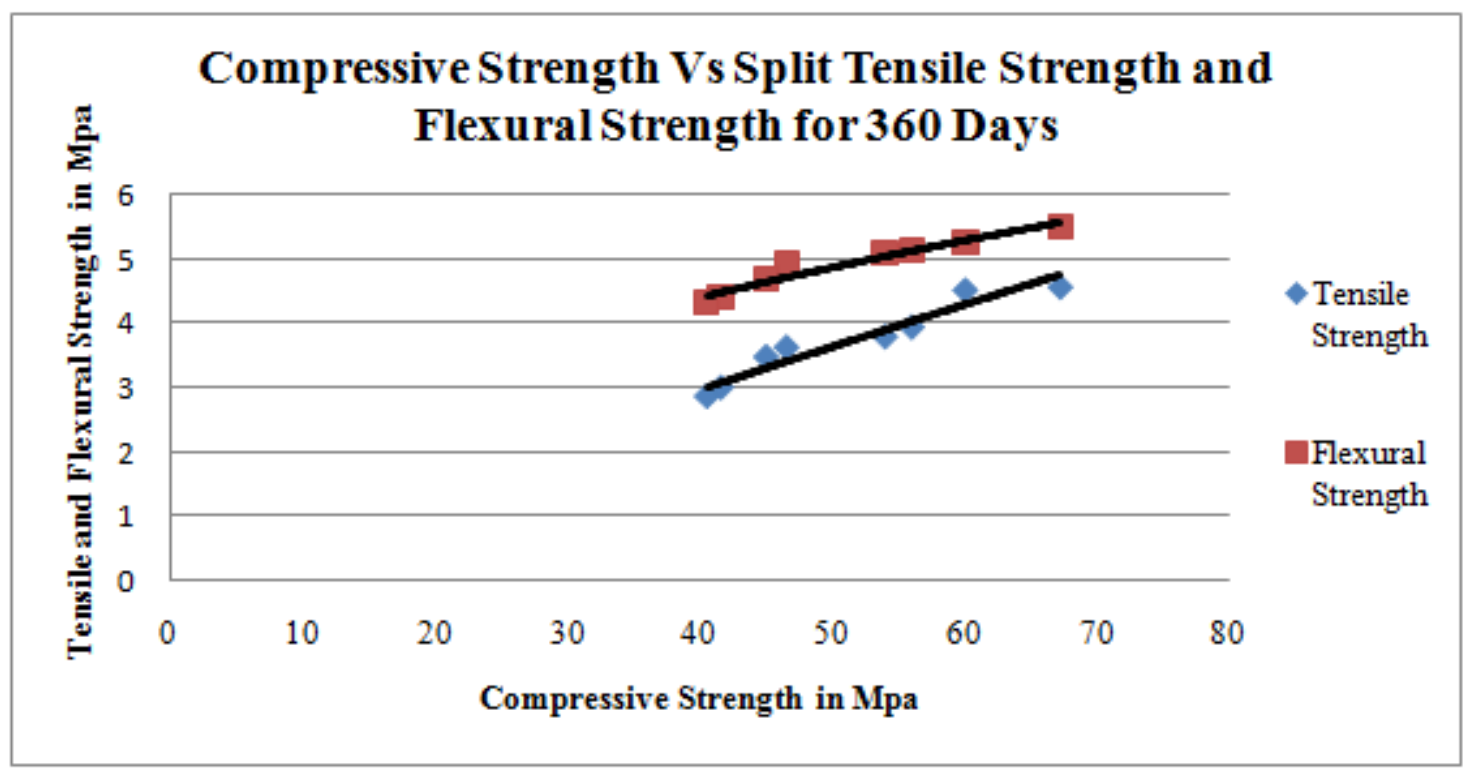

Fig 8 Comparison between Compressive, Split Tensile and Flexural Strengths for 360 Days

\section{TEST RESULTS AND DISCUSSIONS:}

The quantities of materials for one cubic meter of High Volumes of Slag Concrete are shown in table.1. Concrete mixes are designed as per IS : 10262.

The workability of different concrete mixes was measured in terms of Slump values. The test results are given in Table. 1 for High Volumes of Slag Concrete. It can be seen from the table that a medium workability was maintained for almost all the mixes by addition of suitable quantities of super plasticizer.

\subsection{Compressive Strength}

The 28 days compressive strengths for various mixes are given in Table 3.\& Table 4 and Fig.1. The main results indicated that the strengths varies from $29.09 \mathrm{Mpa}$ to $54.0 \mathrm{Mpa}$, $35.60 \mathrm{Mpa}$ to $62 \mathrm{Mpa}, 39.26 \mathrm{Mpa}$ to $65.10 \mathrm{Mpa}$ and $40.55 \mathrm{Mpa}$ to $67.28 \mathrm{Mpa}$ for 28 days, 90 days, 180 days and 360 days of 
High Volumes of Slag Concrete, with water/binder ratios varying from 0.55 to 0.27 respectively. It is observed that an increment in compressive strength 15 to 25 percent for 90 days, 20 to 35 percent for 180 days and 25 to 40 percent with respect to 28 days strengths. It is revealed that the High Volumes of slag concrete gains appreciable amount of strength later ages (90 days onwards).

\subsection{Split Tensile Strength}

From the observations, it is revealed that the rate of strength gain for High volumes of slag concrete is controlled by the slag with time and by its fineness and chemistry of the OPC. Furthermore it can be observed that the considerable amount of strength results of High Volumes of slag concrete appear for long time (180 days). The results are due to slower hydration of slag with $\mathrm{Ca}(\mathrm{OH})_{2}$ and water.

The Split Tensile strengths at 28 days, 90 days, 180 days and 360days for various mixes are given in Table.5.and Fig.2. It is illustrated that the strengths varies from $2.06 \mathrm{Mpa}$ to $3.66 \mathrm{Mpa}$, $2.58 \mathrm{Mpa}$ to $4.19 \mathrm{Mpa}, 2.71 \mathrm{Mpa}$ to $4.38 \mathrm{Mpa}$ and $2.86 \mathrm{Mpa}$ to $4.58 \mathrm{Mpa}$ for High Volumes of Slag Concrete, with water/binder ratios varying from 0.55 to 0.27 respectively. It is observed that an increment in split tensile strength 15 to 25 percent for 90 days, 20 to 35 percent for 180 days and 25 to 40 percent.

\section{Equations for Compressive Strength $\left(f_{c}\right)$ and Split} Tensile strength $\left(f_{t}\right)$ of High Volumes of Slag

\section{Concrete}

Mathematical Equations were obtained expressing Compressive strength and Split Tensile strength for High Volumes of Slag Concrete

Table. 3 \& Table.5 and Fig.5 show the relation between compressive strength and split tensile strength of High Volumes of Slag Concrete at 28days. The equation obtained is

$$
f_{t}=0.10069\left(f_{c}\right)^{0.9019} \text { with ' } \mathrm{R}^{2} \text {, equal to } 0.92 \text {. }
$$

From Table.7 \& Fig.4 the ratio between split tensile strength and compressive strength of High Volumes of Slag Concrete at 28 days varies between $6.47 \%$ and $7.70 \%$.

From Table.3, Table.5 \& Fig.6 the relation between compressive strength and split tensile strength of High Volumes of Slag Concrete at 90days The equation obtained is

$$
f_{t}=0.1221\left(f_{c}\right)^{0.8545} \text { with ' } \mathrm{R}^{2,} \text { equal to } 0.95 \text {. }
$$

From Table.3, Table.5 and Fig.7 shows the relation between compressive strength and split tensile strength of High
Volumes of Slag Concrete at 180days. The equation obtained is

$$
f_{t}=0.0952\left(f_{c}\right)^{0.9187} \text { with ' } \mathrm{R}^{2,} \text { equal to } 0.94 \text {. }
$$

From Table.3, Table.5 and Fig. 8 shows the relation between compressive strength and split tensile strength of High Volumes of Slag Concrete at 360 days. The equation obtained is

$$
f_{t}=0.1050\left(f_{c}\right)^{0.9063} \text { with ' } \mathrm{R}^{2,} \text { equal to } 0.92 \text {. }
$$

\subsection{Flexural strength}

The Flexural strengths at 28 days, 90 days, 180 days and 360 days for various mixes are given in Table. 6 and Fig.3. It can be seen that the strength varies from $3.80 \mathrm{Mpa}$ to $4.76 \mathrm{Mpa}$, $4.12 \mathrm{Mpa}$ to $5.25 \mathrm{Mpa}, 4.22 \mathrm{Mpa}$ to $5.45 \mathrm{Mpa}$ and $4.32 \mathrm{Mpa}$ to $5.50 \mathrm{Mpa}$ for High Volumes of Slag Concrete, with water/binder ratios varying from 0.55 to 0.27 respectively. It is observed that an increment in Flexural strength 5 to 10 percent for 90 days, 10 to 19 percent for 180 days and 14 to 20 percent for 360 days with respect to 28 days. Because of the phenomenon of pozzolanic activity, the strength of HVSC increases with increase in age.

\section{Equations for Compressive Strength $\left(f_{c}\right)$ and Flexural strength $\left(f_{r}\right)$ of High Volumes of Slag Concrete}

Mathematical Equations were obtained expressing Compressive strength and Flexural strength for High Volumes of Slag Concrete.

Table.3, Table.6 and Fig.5 shows the relation between Compressive strength and Flexural strength of High Volumes of Slag Concrete at 28days. The equation obtained is

$$
f_{r}=1.2631\left(f_{c}\right)^{0.3279} \text { with ' } \mathrm{R}^{2,} \text { equal to } 0.95 \text {. }
$$

From Table.7 the ratio between flexural strength and compressive strength of High Volumes of Slag Concrete at 28days, varies between $8.81 \%$ and $13.06 \%$.

Table.3, Table.6 and Fig.6 shows the relation between Compressive strength and Flexural strength of High Volumes of Slag Concrete at 90days. The equation obtained is

$$
f_{r}=0.8667\left(f_{c}\right)^{0.4343} \text { with ' } \mathrm{R}^{2,} \text { equal to } 0.94
$$

Table.3, Table.6 and Fig.7 shows the relation between Compressive strength and Flexural strength of High Volumes of Slag Concrete at 180days. The equation obtained is

$$
f_{r}=0.6895\left(f_{c}\right)^{0.4986} \text { with ' } \mathrm{R}^{2} \text {, equal to } 0.97 .
$$


Table.3, Table.6 and Fig.8 shows the relation between Compressive strength and Flexural strength of High Volumes of Slag Concrete at 360days. The equation obtained is

$$
f_{r}=0.8246\left(f_{c}\right)^{0.454} \text { with ' } \mathrm{R}^{2,} \text { equal to } 0.98
$$

From the results, it is observed that High Volumes of Slag Concrete with water binder ratio 0.27 exhibits good strengths in Compression, Tensile and Flexure at higher ages comparing with other proportions.

\section{CONCLUSIONS}

The following conclusions are drawn from experimental results

- In case of High Volumes of Slag Concrete, the super plasticizer is not added for higher water- binder ratios. However, the workability is maintained.

- The strengths of High Volumes of Slag Concrete are more because of later reaction of GGBFS with $\mathrm{Ca}(\mathrm{OH})_{2}$ and water.

- There is an increase in compressive strength of High Volumes of slag concrete with water/binder ratios varying from 0.55 to 0.27 respectively. Similar pattern is also observed for Split Tensile strength and Flexural Strength.

- The GGBFS used in the investigations exhibits good Pozzolanic properties and can be used in the production of high strength High Volumes of Slag Concrete. High Volumes of GGBFS $50 \%$ can be used as substituting material with good strengths at low water binder ratios.

- An increment in compressive strength 15 to 20 percent for 90 days, 20 to 35 percent for 180 days and 25 to 40 percent for 360 days with respect to 28 days. It is revealed that the High Volumes of slag concrete gains appreciable amount of strength later ages (180 days).

- An increment in split tensile strength 15 to 20 percent for 90 days, 20 to 35 percent for 180 days and 25 to 40 percent for 360 days with respect to 28 days.

- An increment in Flexural strength 5 to 10 percent for 90 days, 10 to 19 percent for 180 days and 14 to 20 percent for 360 days with respect to 28 days.

- The relation between compressive strength and split tensile strength of High Volumes of Slag Concrete at 28 days. The equation obtained is $f_{r}=0.10069(f c)^{0.9019}$ with

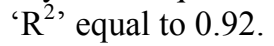

- The relation between compressive strength and Flexural strength of High Volumes of Slag Concrete at 28days. The equation obtained is $f_{r}=1.2631\left(f_{c}\right)^{0.3279}$ with ' $\mathrm{R}^{2}$, equal to 0.95 .

- On replacement of cement by 50\% GGBFS helps to reduce the cement content of concrete, thereby reducing the cost of concrete.

- Reuse of the slag helps to protect the environment from pollution.

\section{REFERENCES}

[1] Md. Moinul Islam, Md.Saiful Islam, Bipul Chandra Mondal and Mohammad Rafiqul Islam "Strength behavior of concrete using slag with cement in sea water environment" Journal of Civil Engineering (IEB), 38 (2) (2010) 129-140.

[2] Information on http://www.icaemt.org

[3] Roy,D.M.adn Idorn,G.M., "Hydration, structure and properties of blast-furnace slag cementmortals, and concrete", ACI journal (79) (1982) 444-457

[4] Wimpenny, D.E., Ellis, C. Reeves, C.M. and Higgins, D.D., "The development of strength and elastic properties in slag cement concretes under low temperature curing conditions", Proc. OfThird CANMET/ACI International conference on fly ash, silica fume, slag, and naturalpozzolans in concrete, Trondheim, Norway, June 18-23, 1989, (editor, V.M. Malhotra, ACI special publ., SP-114, 1989) 1283-1306.

[5] A1-Kaisi, A.F., "Early Age Strength and Creep of Slag Cement Concretes", PhD thesis, Department of Civil Engineering, The University of Leeds (August 1989).

[6] Pratas, J.D., "Early age strength development of slag cement concretes", MSc. Dissertation, University of Leeds, 1978.

[7] Sasan Parniani1, a, Mohd.Warid Hussin2, b and Farnoud Rahimi Mansour"Compressive strength of high volume slag cement concrete in high temperature curing"Advanced Materials Research Vols. 287-290 (2011) pp 793-796.

[8] David N. Richardson University of MissouriRolla"Strength and Durability Characteristics of a 70\% Ground Granulated Blast Furnace Slag (GGBFS) Concrete Mix"Orgnizational Research Report. February 2006, RI99.035, RI99.035B.

[9] Atul Dubey, Dr. R. Chandak, Prof. R.K.Yadav "Effect of blast furnace slag powder on compressive strength of concrete"International Journal of Scientific \& Engineering Research Volume 3, Issue 8, August-2012 1 ISSN 2229-5518.

[10] Mohd Warid Hussin, Lim Siong Kang, Fadhadli Zakaria“Engineering Properties Of High Volume Slag Cement Grout In Tropical Climate"Malaysian Journal of Civil Engineering 19(1) : 42-54 (2007).

[11] Irene K. LaBarca, Ryan D. Foley, Steven M. Cramer,University of Wisconsin - Madison Department of Civil and Environmental Engineering "Effects of Ground Granulated Blast Furnace Slag in Portland Cement Concrete - Expanded Study" WISCONSIN HIGHWAY RESEARCH PROGRAM \#0092-05-01.

[12] Mohammed Nadeem, Arun D Pofale"Experimental Investigation of using slag as an alternative to normal aggregates (coarse and fine) in concrete", International Journal of Civil and Structural Engineering, Volume 3, No 1, 2012. 
[13] P. Venkata Mallikarjun Rao, G. Rajendra , M. Suyra Teja, S.Kanakambara Rao "Influenceof Slag on Steel Fiber Reinforced Self Compacting Concrete"INTERNATIONAL JOURNAL OF ADVANCED SCIENTIFIC RESEARCH AND TECHNOLOGY, ISSUE 2, VOLUME 2 (APRIL 2012), ISSN: 2249-9954

[14] VENU MALAGAVELLI, P. N. RAO "HIGH PERFORMANCE CONCRETEWITH GGBS AND ROBO SAND"Venu Malagavelli et. al. / International Journal of Engineering Science and Technology, Vol. 2(10), 2010, 5107-5113.

[15] Yousef Zandil and Vefa Akpinar M.2, "An Experimental Study on Separately Ground and together Grinding Portland Slag Cements Strength Properties"Research Journal of RecentSciences, Vol. 1(4), 27-40, April (2012), ISSN 2277-2502, Res.J.Recent Sci.

[16] Gopal Charan Behera*, Er. Monika Mohanty, Sudeep Roghan Bagh, "Slag as coarse aggregate and its effect on mechanical properties of concrete" Scholarly Journal of Engineering Research Vol. 1(4), pp. 60-66, September 2012, Available online at http:// www.scholarly-journals.com/SJER, ISSN 2276-8955 (C)2012 Scholarly-Journals. 